\title{
The Effect of Small Step Reading Method and Stepping Stone Method on The Ability of Beginning Reading of Elementary School Students
}

\author{
Muhamad Taufik Hidayat ${ }^{1}$ and Wahyu Pambudy Astuti ${ }^{2}$ \\ \{mt.hidayat@ums.ac.id ${ }^{1}$ and a510150011@student.ums.ac.id ${ }^{2}$ \} \\ 1,2 Elementary School Teacher Education, Universitas Muhammadiyah Surakarta, Surakarta, Indonesia
}

\begin{abstract}
Some factors influence the difficulty of students in beginning reading. One of them is the selection of the method. The purposes of this study are; (1) to determine the ability difference of beginning reading by spelling method and SSR (Small Step Reading) method (2) to determine the ability difference of beginning reading by spelling method and Stepping Stone method, and (3) to determine the more effective method between SSR method and Stepping Stone Method. This quantitative study was a quasi experiment with a nonequivalent control group design. Subjects of this study were 51 first grade students of Islamic Elementary School Gonilan (MI Muhammadiyah Gonilan), Central Java, Indonesia. Data collection did with some tests including normality with Saphiro Wilk test, homogeneity with F-test, as well as a hypothesis with t-test. The findings of this study showed; (1) there was an ability difference of beginning reading by spelling method and SSR (Small Step Reading) method (2) there was an ability difference of beginning reading by spelling method and Stepping Stone method, and (3) SSR method was more effective than Stepping Stone Method based on t-count (1.952) > t-table (1.676).
\end{abstract}

Keywords: Small Step Reading Method, Stepping Stone Method, Beginning Reading, Elementary School Student

\section{Introduction}

The ability of beginning reading is the reading potential of children in an early-stage such as reading symbols and images. The purposes of beginning reading in the lower class are to recognize the letters and arrange the letters so the children can read. At the beginning reading stage, children are learning the writing system, how to achieve reading fluency, as well as integrate sound and writing system. Accuracy and success in the beginning reading stage would give an influential impact on the next level of reading skill [1].

The inability of elementary school students in beginning reading is a serious problem. The beginning reading inability of students would lose their motivation in learning. Besides, the undressed inability of beginning reading would rise low performance in class, desperate feeling, student misbehaviour, and drop out of school [1]. The students with the problem of beginning reading should get treatment as early as possible.

Dimensions of students with difficulty in beginning reading such as; not fluent in reading, too many mistakes in reading, unable to distinguish among similar letters, bad visual memory, and unable to understand the sound symbols. Based on the other studies also found the 
difficulties in beginning reading are; inability to analyze letters, unability to recognize letters or words generally, a misconception that the omitted letters or words are unneeded, and inability to understand the relationship between letters and sounds in word [2].

Several studies of beginning reading have conducted. Stepping Stone is a new method of beginning reading for lower grade students [3]. SSR method is proven to improve students' reading ability [4]. The implementation of MMP (Membaca Menulis Permulaan) method for elementary school students is quite successful [5]. Four methods used by teachers in teaching beginning reading are the Sound Method, Alphabet Method, Syllables Method and Kata Lembaga Method [6]. There are seven effective beginning reading programs for kindergarten to third-grader students, namely: Kindergarten Peer-Assisted Learning Strategy (K-PALS), Peer Tutor, Stepping Stone to Literacy, Sound Partners, Fast for Word Reading 1 (FFW1), Reading Recovery, Corrective Reading, and Wilson's Reading System [7]. The last one, the implementation of Stepping Stone method can increase the students' interest in literacy [8].

Despite these past studies, not many of them focused on comparison among these methods, especially the most effective ones. That fact left a gap for more studies to do in Indonesia. Based on the problem statement above, the purposes of this study are; (1) to determine the ability difference of beginning reading by spelling method and SSR method (2) to determine the ability difference of beginning reading by spelling method and Stepping Stone method, and (3) to determine the more effective method between SSR method and Stepping Stone method.

The authors proposed these following hypotheses:

Hypothesis 1

$\mathrm{H}_{0}$ : There is no difference in beginning reading ability by spelling method and SSR method.

$\mathrm{H}_{1}$ : There is a difference in beginning reading ability by spelling method and SSR method.

Hypothesis 2

$\mathrm{H}_{0}$ : There is no difference in beginning reading ability by spelling method and Stepping Stone method.

$\mathrm{H}_{1}$ : There is a difference of beginning reading ability by spelling method and Stepping Stone method.

Hypothesis 3

$\mathrm{H}_{0}$ : SSR method is no more effective in beginning reading than The Stepping Stone method.

$\mathrm{H}_{1}$ : SSR method is more effective in beginning reading than The Stepping Stone method.

\section{Method}

\subsection{Type and Design}

The method used in this study was a quasi-experimental with a quantitative approach. The study design was the Nonequivalent Control Group Design. In this study, there were two groups with different treatment. The authors gave the first group the SSR method (X1), and gave the second group The Stepping Stone method (X2). The first group was called the experiment class 1 , and the second group was called the experiment class 2 . The study design is presented in Table 1. 
Table 1. Study Design

\begin{tabular}{ccccc}
$\begin{array}{c}\text { Initial } \\
\text { Condition }\end{array}$ & Group & Taking & Treatment & $\begin{array}{c}\text { Final } \\
\text { Conditions }\end{array}$ \\
\hline Pretest & $\begin{array}{c}\text { Experiment } \\
\text { class 1 }\end{array}$ & I & SSR Method & Post Test \\
Pretest & $\begin{array}{c}\text { Experiment } \\
\text { class 2 }\end{array}$ & I & $\begin{array}{c}\text { Stepping } \\
\text { Stone Method }\end{array}$ & Post Test \\
\hline
\end{tabular}

The study steps were:

- Determined the experiment class 1 and 2.

- Validated the pretest and postest items

- Provided a pretest

- Provided treatment for each classes

- Provided a posttest

- Analyzed the data with statistical tests

\subsection{Place and Time of Study}

This study was conducted at MI Muhammadiyah Gonilan located in Tuwak, Gonilan, Kartasura, Sukoharjo, Central Java, Indonesia. At this elementary school, especially in first grade, were still experiencing difficulties in beginning reading. This study conducted during June 2019.

\subsection{Subject}

The subjects in this study were all first grader students of MI Muhammadiyah Gonilan in the 2019/2020 (n=51). All students spread into two classes, 26 students who were experiment class 1 and 25 students who were experiment class 2.

\subsection{Data Collection Techniques and Instruments}

Data collection technique is the most strategic step in the study because the main purpose of study is to get data [9]. The authors employed several tests for collecting the data. The tests consist of item validity test, item reliability test, level of difficulty test, pretest, normality test, homogeneity test, hypothesis test, and postest.

\section{Item Validity}

To analyzed the item validity, the authors used Correlation Product Moment [10].

$$
\mathrm{r}_{\mathrm{xy}}=\frac{\mathrm{n} \Sigma x_{1} y_{1}-\left(\Sigma x_{1}\right)\left(\Sigma y_{1}\right)}{\left.\sqrt{\left\{n \Sigma x_{1}^{2}\right.}-\left(\Sigma x_{1}\right) 2\right\}\left\{n \Sigma y_{1}^{2}-\left(\Sigma y_{1}\right) 2\right\}}
$$

Note :

$\mathrm{r}_{\mathrm{xy}}=$ correlation between variable $\mathrm{x}$ and $\mathrm{y}$

$\mathrm{x}=\mathrm{x}_{1}-\mathrm{X}$

$\mathrm{y}=\mathrm{y}_{1}-\mathrm{y}$

The item is valid if the value of $r$-count $\geq$ r-table with $\alpha=0.05$. Otherwise, if the value of $r$ count $<\mathrm{r}$-table, then the item is invalid. $\mathrm{df}=\mathrm{n}-2$, in finding $\mathrm{r}$-table. 


\section{Item Reliability}

Reliability testing was done internally by analyzing the consistency of items on the instrument with the Cronbach Alpha technique [11]:

$$
\mathrm{r}_{\mathrm{i}}=\frac{k}{(k-1)}\left\{1-\frac{\Sigma S_{I}^{2}}{S_{t}^{2}}\right\}
$$

Note:

$r_{1}=$ instrument reliability coefficient

$\mathrm{k}=$ number of statement items

$\Sigma S_{I}^{2}=$ total item variance

$S_{t}^{2}=$ total variance

The item is reliable if the value of $r$-count $\geq$ r-table with $\alpha=0.05$. Otherwise, if the value of $\mathrm{r}$-count $<\mathrm{r}$-table then the item is not reliable. $\mathrm{df}=\mathrm{n}-2$ in finding r-table,.

\section{Level of Difficulty}

To find out the level of difficulty for each item, the authors used:

$$
\mathrm{IK}=\frac{x}{S M I}
$$

Note :

IK = Level of difficulty

$\mathrm{x}=$ Average Score

$\mathrm{SMI}=$ Ideal Maximum Score for each item

\subsection{Data Analysis Technique}

The analysis performed by statistical descriptive.

\section{Analysis Prerequisite Test}

a) Normality Test

Test normality did use Saphiro Wilk test. Data is normal when the calculated p values are between $\alpha(0.10)$ and $\alpha(0.5)$ above the $\alpha$ value $(0.05)$.

$$
\mathrm{T}_{3}=\frac{1}{D}\left[\sum_{i-1}^{k} a_{i}\left(X_{n-i+1}-X_{i}\right)\right]^{2}
$$

\section{b) Homogeneity Test}

In this study, the homogeneity test used the F-test. To found out the homogeneity results, a calculation was performed to found the F-count value used the formula:

$$
\mathrm{F}=\frac{\text { Biggest } \text { Variance }}{\text { Smallest } \text { Variance }}
$$

If F-count $<$ F-table then the data is homogeneous, whereas if F-count $>$ F-table then the data is not homogeneous. 


\section{Hypothesis Test}

An independent t-test was used to found out the differences in the mean of two independent population or data groups.

To answered the hypotheses 1 and 2, the authors did dependent t-test with formula as follows :

$$
\mathrm{t}=\frac{x_{1}-x_{2}}{\sqrt{\frac{s_{1}^{2}}{n_{1}}+\frac{s_{2}^{2}}{n_{2}}-2 r\left(\frac{s_{1}}{\sqrt{n_{1}}}\right)\left(\frac{s_{2}}{\sqrt{n_{2}}}\right)}}
$$

Note:

$\mathrm{X}_{1}=$ sample mean value (pretest)

$\mathrm{x}_{2}=$ sample mean value (posttest)

$\mathrm{s}_{1}^{2}=$ data variance (pretest)

$\mathrm{s}_{2}^{2}=$ data variance (posttest)

$\mathrm{s}_{1}=$ standard deviation (pretest)

$\mathrm{s}_{2}=$ standard deviation (posttest)

$\mathrm{n}_{1}=$ number of students (pretest)

$\mathrm{n}_{2}=$ number of students (posttest)

$\mathrm{r}=$ correlation between the two samples (pretest and postest)

While to answered the hypotheses 3, the authors did independent t-test with formula as follows :

$$
\mathrm{t}=\frac{x 1-x 2}{\sqrt{\frac{S_{1}^{2}}{n_{1}}+\frac{S_{2}^{2}}{n_{2}}}}
$$

Note :

$\mathrm{X}_{1}=$ sample mean value (experiment class 1$)$

$\mathrm{x}_{2}=$ sample mean value (experiment class 2$)$

$\mathrm{s}_{1}^{2}=$ data variance (experiment class 1$)$

$\mathrm{s}_{2}{ }^{2}=$ data variance (experiment class 2 )

$\mathrm{n}_{1}=$ number of students (experiment class 1 )

$\mathrm{n}_{2}=$ number of students (experiment class 2 )

\section{Result}

\subsection{Instrument Trial Data Analysis}

\section{Item Validity Test}

The result of item validity test as follows: 
Table 2. Item Validity Results

\begin{tabular}{cccc}
\hline $\begin{array}{c}\text { Item } \\
\text { No }\end{array}$ & $\begin{array}{c}\text { R- } \\
\text { count value }\end{array}$ & $\begin{array}{c}\text { Value of } \mathrm{r}- \\
\text { table } \alpha=5 \%\end{array}$ & Information \\
\hline 1 & 0.9924 & & Valid / usable \\
2 & 0.9923 & & Valid / usable \\
3 & 0.9955 & & Valid / usable \\
4 & 0.9967 & & Valid / usable \\
5 & 0.9941 & \multirow{2}{*}{0.281} & Valid / usable \\
6 & 0.9928 & & Valid / usable \\
7 & 1.4969 & & Valid / usable \\
8 & 0.9782 & & Valid / usable \\
9 & 0.9642 & & Valid / usable \\
10 & 0.9104 & & Valid / usable \\
\hline
\end{tabular}

The beginning reading test was conducted using oral questions consisting of 10 items. After tested the validity of the items using the Product Moment Correlation from Karl Pearson [10], the results of all items are stated by following with the criteria $r$-count $\geq$ r-table, then the item is valid. Based on Table 2, the value of $r$-count for the whole item is higher than the value of $r$ table (0.281). It is meant that the instrument test is valid or usable.

\section{Item Reliability Test}

The reliability test used the Cronbach Alpha technique [11] to 10 items. All items in the experiment class 1 and 2 were obtained 14.616 a total item variance. Meanwhile, for total variance was obtained 101.6539. That means the alpha value was 0.9513 . The instrument reliability coefficient

The $\mathrm{r}$-table value for $\mathrm{n}=51$ with $\mathrm{df}=\mathrm{n}-2$ using $\alpha=5 \%$ is 0.281 . It can be concluded that the instrument was reliable because the r-count $(0.9513)>$ r-table $(0.281)$.

\section{Level of Difficulty}

The level of difficulty of each item are presented in Table 3:

Table 3. Level of Difficulty of Items

\begin{tabular}{ccc}
\hline Item No & Level of Difficulty & Interpretation \\
\hline 1 & 0.912 & Easy \\
2 & 0.882 & Easy \\
3 & 0.767 & Easy \\
4 & 0.692 & Easy \\
5 & 0.624 & Medium \\
6 & 0.578 & Medium \\
7 & 0.592 & Medium \\
8 & 0.501 & Medium \\
9 & 0.503 & Medium \\
10 & 0.363 & Medium \\
\hline
\end{tabular}

Based on the level of difficulty classification, the item numbers 1,2, 3, and 4 were easy while the item numbers $5,6,7,8,9$ and 10 were medium. 


\subsection{Pretest Data Analysis}

To determined whether the two groups originated from the same initial ability, a pretest was conducted. Pretest did before applied the SSR method and Stepping Stone method.

\section{Normality Test}

Normality test was performed to determine whether the experiment class 1 and 2 data were normally distributed or not. Test normality did use Saphiro Wilk test. Data is said to be normal when the calculated $\mathrm{p}$ values are between $\alpha(0.10)$ and $\alpha(0.5)$ above the $\alpha$ value $(0.05)$. The results of the Saphiro Wilk test are shown in table 3 as follows:

Table 4. Pretest Data Normality Test

\begin{tabular}{ccc}
\hline Statistics & Experiment Class 1 & Experiment Class 2 \\
\hline N Sample & 26 & 25 \\
$\alpha(0.10)$ & 0.933 & 0.931 \\
$\alpha(0.5)$ & 0.965 & 0.964 \\
$\mathrm{P}$ & 0.9539 & 0.9613 \\
proportion gained & 0.1314 & 0.1949 \\
& \multicolumn{3}{c}{ Normal } \\
\hline
\end{tabular}

Table 4 shows that the value of the proportion gained from the Saphiro Wilk trial of experiment class 1 and experiment class 2 respectively is 0.1314 and 0.1949 . The second value of the $p$ is above the value of $\alpha=0.05$. It can be concluded that the sample of experiment class 1 and experiment class 2 were normally distributed.

\section{Variance Homogeneity Test}

Homogeneity test aimed to determine whether both samples have homogeneous variance or not. The authors used the F-test. The data is homogeneous if F-count $\angle F$-table, and not homogeneous if F-count>F-table. To find the F-count, using the formula:

$$
\begin{aligned}
\text { F-count } & =\frac{\text { Biggest } \text { Variance }}{\text { Smallest } \text { Variance }} \\
& =\frac{10.218}{19.949} \\
& =1.027
\end{aligned}
$$

Based on the data calculation, the F-count $<$ F-table $(1.027<1.96)$. The sample is homogeneous at a $95 \%$ confidence level.

\subsection{Posttest Data Analysis}

\section{Data Normality Test}

The results of the posttest data normality of the experiment class 1 and experiment class 2 are shown in Table 5: 
Table 5. Posttest Data Normality Test

\begin{tabular}{ccc}
\hline Statistics & Experiment Class 1 & Experiment Class 2 \\
\hline N Samples & 26 & 25 \\
$\alpha(0.10)$ & 0.933 & 0.931 \\
$\alpha(0.5)$ & 0.965 & 0.964 \\
$\mathrm{P}$ & 0.9641 & 0.9446 \\
proportion gained & 0.2005 & 0.1894 \\
& \multicolumn{3}{c}{ Normal } \\
\hline
\end{tabular}

Based on these data, it can be concluded that the both classes were normally distributed.

Variance Homogeneity Test

$$
\begin{aligned}
& F_{\text {count }}=\frac{\text { Biggest Variance }}{\text { Smallest Variance }} \\
& =\frac{11,902}{9,113} \\
& =1,306
\end{aligned}
$$

Based on the data calculation, the F-count < F-table $(1.306<1.96)$, it can be concluded that the sample was homogeneous at a $95 \%$ confidence level.

\section{Hypothesis Test}

After the prerequisite tests analysis, the hypothesis test was performed using the t-test. Hypothesis 1

This is the result of t-count by spelling method and SSR method.

$$
\begin{aligned}
\mathrm{t}= & \frac{x_{1}-x_{2}}{\sqrt{\frac{s_{1}^{2}}{n_{1}}+\frac{s_{2}^{2}}{n_{2}}-2 r\left(\frac{s_{1}}{\sqrt{n_{1}}}\right)\left(\frac{s_{2}}{\sqrt{n_{1}}}\right)}} \\
& =\frac{61,12-83,81}{\sqrt{\frac{98,99}{26}+\frac{83,04}{26}-2.0,9007\left(\frac{9,95}{\sqrt{26}}\right)\left(\frac{9,11}{\sqrt{26}}\right)}} \\
= & -76,351
\end{aligned}
$$

$\mathrm{t}$-table value with $\mathrm{dk}=26+26-2=50$ and an error level set of $5 \% \mathrm{t}$-table $=1.675$. So, $\mathrm{t}$-count $-76,351<\mathrm{t}$-table $1.675<\mathrm{t}$-tabel $1.975 . \mathrm{H}_{1}$ is accepted and $\mathrm{H}_{0}$ is rejected that mean there is an ability difference of beginning reading by spelling method and SSR method.

\section{Hypothesis 2}

This is the result of t-count by spelling method and stepping stone method. 


$$
\begin{aligned}
t & =\frac{x_{1}-x_{2}}{\sqrt{\frac{s_{1}^{2}}{n_{1}}+\frac{s_{2}^{2}}{n_{2}}-2 r\left(\frac{s_{1}}{\sqrt{n_{1}}}\right)\left(\frac{s_{2}}{\sqrt{n_{1}}}\right)}} \\
& =\frac{58,00-78,00}{\sqrt{\frac{104,42}{25}+\frac{141,67}{25}-2.0,867\left(\frac{10,22}{\sqrt{25}}\right)\left(\frac{11,90}{25}\right)}}
\end{aligned}
$$

$=-16,820$

$\mathrm{t}$-table value with $\mathrm{dk}=25+25-2=48$ and an error level set of $5 \% \mathrm{t}$-table $=1.672$. So, $\mathrm{t}$-count $-16,820<$-t-table1.672<t-table $1.672 . \mathrm{H}_{1}$ is accepted and $\mathrm{H}_{0}$ is rejected that mean there is an ability difference of beginning reading by spelling method and Stepping Stone method.

\section{Hypothesis 3}

This is the result of the t-test.

$$
\begin{aligned}
& \mathrm{t}=\frac{x 1-x 2}{\sqrt{\frac{s_{2}^{1}}{n_{1}}+\frac{s_{2}^{2}}{n_{1}}}} \\
& \mathrm{t}=\frac{83,81-78,00}{\sqrt{\frac{83,04}{26}}+\frac{141,67}{25}} \\
& \mathrm{t}=1,952
\end{aligned}
$$

$\mathrm{t}$-table value with $\mathrm{dk}=51-2=1.672$. So, $\mathrm{t}$-count $1.952>\mathrm{t}$-table $1.676 . \mathrm{H}_{1}$ is accepted and $\mathrm{H}_{0}$ is rejected that mean SSR method is more effective on beginning reading than The Stepping Stone method.

\section{Discussion}

Based on the result, there was a difference in the result of students' beginning reading using the spelling method and the SSR method. The SSR method provides positive changes to the students' beginning reading skills. There are five levels in teaching children to read with the SSR method. The five levels have been adjusted to the child's initial ability. Another influential factor is the appearance of media in the SSR method. In the SSR method, there are pictures and fragments of words that have been coloured to attract and make it easier for children to read. With the pictures and colours in the fragments of words can help children learn to read.

According to one of the factors that can influence students' initial reading ability is a psychological factor [13]. The psychological factor here includes children's motivation and interest in reading activities. With the pictures and coloured fragments of the SSR method, it can attract students in learning to read and motivate students to enjoy learning to read. When students have no burden and feel happy in learning to read the situation will have a positive effect on the results of the ability to read. That is why the SSR method has a positive influence 
on students' initial reading ability compared to using the spelling method, which is less attractive to students.

The Stepping Stone method also has a significant impact on improving students' beginning reading skill. First, It is because The Stepping Stone method is a new method. Second, in reading lesson using The Stepping Stone method, students are not allowed to read by spelling.

According to the result of Sasongko's research [14], teaching children to read by spelling would slow children to master beginning reading skills. Children who are taught to read by spelling method experience some difficulties understanding how to pronounce certain words in a reading text.

From these data, it can be seen that by using the SSR method is more effective than by using The Stepping Stone method. The factor that influences the SSR method is more effective is there are images that attract students to read. Besides, there are fragments of words with special colour to help students learn to read without spelling. With the pictures and fragments of words, the students can understand the material easier. In the opinion of Fahmi [15], six to seven years old children do not have a fixed emotion. Children still often feel afraid of doing a certain activity. Therefore it is very important in choosing the right reading method for the students' conditions to create a pleasant learning experience.

According to research [16], the SSR method can improve the ability to read double vowels for children with difficulty reading in grade four of elementary school. According to the result of this study, the application of the SSR method in beginning reading can improve students' initial reading skills in grade I elementary school. By using the SSR method, students' reading difficulties can be overcome, students' ability to master reading skills is increased. It can be concluded that in addition to being applied to upper classes, the SSR method in reading lessons can also be applied to lower class students.

The Stepping Stone method is not suitable for students in first-grade of elementary school. One very influential factor is a rule that students are not allowed to learn the next step if they cannot read at the previous level. Students must be able to master one by one at each step of the reading material. These rules slow down students in learning the beginning reading material. This rules causes the result of the ability to read with The Stepping Stone method is no more effective than the SSR method.

The conclusion, The Stepping Stone method is still too difficult to use in first-grade students in elementary school. Besides, The Stepping Stone Method takes too long for students to learn at each reading stage. The Stepping Stone method would be appropriate for children who learn to read privately or outside the teaching and learning process at school. For example reading lessons or reading and learning activities with parents at home. In this study, the external variables are not tightly controlled. It can influence the study such as learning styles and learning environment.

\section{Conclusion}

Right planning and selection of learning method can affect the students' achievement. SSR method usable as one of interesting learning method for students. SSR method not only usable for the beginning reading lesson but also various learning materials. It is essential for train Elementary School Teacher Education students the SSR method. 


\section{References}

[1] R.E. Slavin, Membaca Membuka Pintu Dunia: Program Success for All: Model yang Jelas dan Kuat untuk Meningkatkan Kemampuan Membaca Anak Sekolah Dasar [Reading Opens the Door of World: Program Success for All: A Clear and Strong Model to Improve Reading Skills of Elementary School Children], 2nd ed. Yogyakarta: Pustaka Pelajar, 2014.

[2] Masropah, "Studi Deskriptif Jenis-Jenis Kesulitan Belajar Membaca dan Menulis Permulaan Siswa Kelas II Sekolah Dasar Kelurahan Sawah Lebar Lama, Kota Bengkulu [The Descriptive Study of Types of Difficulties in Beggining Reading and Writing Learning of Second Grade Students of Sawah Lebar Lama Elementary School, Bengkulu City]," Undergraduate Thesis, Universitas Bengkulu, 2014.

[3] J. R. Nelson, "Stepping stones to literacy," Spec. Educ. Commun. Disord. Fac. Publ., vol. 72, no. 1, pp. 29-45, 2014.

[4] M. F. Auliya, Smart Reading, 1st ed. Yogyakarta: Pustaka Widyatama, 2017.

[5] E. D. Hapsari, "Penerapan Membaca Permulaan untuk Meningkatkan Kemampuan Membaca Siswa [The Application of Beginning Reading to Improve Students' Reading Ability]," vol. 20, no. 1, pp. 10-24, 2019.

[6] A. Muhyidin, O. Rosidin, and E. Salpariansi, "Metode Pembelajaran Membaca dan Menulis Permulaan di Kelas Awal [Beggining Reading and Writing Learning Method in Lower Grade]," JPSD, vol. 4, no. 1, p. 13, 2018.

[7] F. M. Hollands et al., "Improving early literacy : Cost-effectiveness analysis of effective reading programs," Cent. Benefit-Cost Stud. Educ. Teach. Coll. Colomb. Univ., no. April, p. 65, 2013.

[8] S. Sharla L and J. M. Foster, "Stepping Stones for Linking, Learning, and Moving Toward Electronic Literacy: Integrating Emerging Technology in an Author Study Project," Comput. Sch., no. 915529996, pp. 37-41, 2014.

[9] Sugiyono, Metode penelitian kuantitatif, kualitatif dan $R \& D$ [The Research Method of Quantitative, Qualitative and R \& D]. Bandung: Alfabeta, 2015.

[10] K. Pearson, Early Statistical Papers. England: University Press, 1948.

[11] L. J. Cronbach, "Coefficient alpha and the internal structure of tests," Psychometrika, 1951.

[12] S. S. Shapiro and M. B. Wilk, "Biometrika Trust An Analysis of Variance Test for Normality (Complete Samples)," Source Biometrika Biometrika Trust, 1965.

[13] P. Lamb and R. Arnold, Teaching Reading: Foundations and Strategies. Michigan: Wadsworth Pub, 1980.

[14] A. Sasongko, "Meningkatkan Akurasi Alih Aksara Alfabet-Jawi Bahasa Indonesia Menggunakan Pendekatan FSA [Improving the Accuracy of transliteration of Alphabet-Jawi in Bahasa Indonesia Using FSA Approach]," J. Inform. UBSI, vol. 3, no. September, pp. 259-268, 2016.

[15] F. Ismail, Keberagaman Anak Usia Sekolah Dasar [The Diversity of Elementary School Children] . Jakarta: Bumi Aksara, 2015.

[16] M. Akbar, "Efektifitas Metode Smart Reading Untuk Meningkatkan Kemampuan Membaca Permulaan bagi Anak Kesulitan Membaca [The Effectiveness of the Smart Reading Method for Improving Beginning Reading Ability of Children with Reading Difficulties]," E-JUPEKhu (JURNAL Ilm. Pendidik. KHUSUS), vol. 4, no. September, pp. 175-182, 2015. 